\title{
FRAGMENTA
}

\section{COMICORVM GRAECORVM}

COLLEGIT ET DISPOSVIT

\section{AVGVSTVS MEINEKE}

E D I T I O M I N O R

PARS I

B E R O L I N I

TYPIS ET IMPENSIS G. REIMERI

MDCCCXLVII 
